\title{
THE IMPACT OF POTASSIUM FERTILIZATION ON DEVELOPMENT AND MAGNESIUM CONTENT OF CELERY
}

\author{
Imre Cserni ${ }^{1}$ Attila Hüvely ${ }^{2}$, Judit Petö ${ }^{*}$ \\ ${ }^{1}$ professor emeritus of the Faculty of Horticulture and Rural Development, John von Neumann University, \\ Kecskemét, Hungary \\ 2 Department of Agricultural Science, Faculty of Horticulture and Rural Development, John von Neumann \\ University, Kecskemét, Hungary \\ https://doi.org/10.47833/2020.1.AGR.014
}

\begin{abstract}
Keywords:
Lysimeter pot

Potassium fertilizer

Celery

Magnesium content

Tuber mass
\end{abstract}

Article history:

Received 1 Nov 2019

Revised 25 Nov 2019

Accepted 5 Dec 2019

\begin{abstract}
Our experiments were carried out in 2017, in our study garden. Celery test plant was used, in lysimeter-type, large-sized breeding pots, in four series. Four different treatments of potassium fertilizer and manure was used. The results show that potassium fertilization in celery test plants increased potassium in a dose-dependent manner. Potassium fertilizer decreased magnesium nutrient content in the leaves and roots. Our results call attention for magnesium supplementation in parallel with potassium fertilization. Positive effect of potassium on tuber growing was also shown. Total plant weight was the highest after the organic manure treatment.
\end{abstract}

\section{Introduction}

In Hungary, sandy soils belonging to the main type of skeletal soils - sand and loamy sandy soils - make up approximately $30 \%$. The area of these sandy soils is 615 thousand hectares in the Danube-Tisza sandbank [11, 15].

Examining the mechanical composition of Hungarian soils, about $16 \%$ is sand and $10 \%$ is sandy loam [18]. The soil in our experiment is the soil of so called "running sand" (borbás puszta).

One fourth of our soils are considered potassium-poor. This also means that our sandy soils have poor K-supply capacity [13]. These soils are poor in clay minerals of the illite, chlorite and kaolinite type, and their organic matter content is also very low: $0.3-1.2 \%$ [16]. The total $\mathrm{K}$ content of the soils is $0.2-3.3 \%$, of which only a small part can be utilized for the plants. Potassium is found in the soil solution in the form of $\mathrm{K}$-ion, on the surface of colloids (in an exchangeable form as adsorbed ions), and bound in clay minerals and primary potassium minerals (in an irreplaceable form) [14].

The exchangeable potassium is bound to the natively charged sites of clay minerals and organic matter in the form of a hydrated ion. In plants, potassium remains in the ionic form and can be washed out of organic matter after the plants die. Therefore, only the presence of inorganic potassium in the soil is expected. In the soil solution, a balance is reached between the exchangeable and non-exchangeable $\mathrm{K}^{+}$ion content. However, we do not expect potassium to bind to our sandy soils because of their low clay content and thus selective binding is low $[6,7,9,12,13$, 14]. It is important according to nutrient supply of vegetable plants that the nutrient supply should be continuously ensured during the growing period according in all development stages of the plant [17].

\footnotetext{
* Corresponding author. Tel.: +36 76517661

E-mail address: peto.judit@kvk.uni-neumann.hu
} 
Whether we are consuming celery tuber or celery leaf, this vegetable is becoming increasingly popular these days. Celery leaf and tuber give a fragrant, aromatic, sweetly tart taste. Celery is a popular root vegetable, an essential part of Hungarian cuisine.

In our experiment the effect of potassium nutrient on celery crop elements was analyzed in a large lysimeter experiment in Kecskemét on calcareous sandy soil. Potassium leaching from soil has already been studied in this system $[3,4,5]$.

\section{Materials and methods}

For decades, we have made studies in pot cultivation, in the study garden of the Faculty of Horticulture, using different vegetable and field crop cultures and applying different types and amounts of fertilizer treatments. The present experiments were carried out in the inner garden of the Department of Agricultural science in 2017. The soil of the experiment was sand, the main type of skeletal soils, filled into flush lysimeter-type cultured pots of $0.3 \mathrm{~m}^{2}$ surfaces. Six treatments were applied in the random block arrangement using rain-like irrigation. The experiments were performed in four replicates.

Celery (Apium graveolens convar. Rapaceum) was the test plant for the experiment (Fig. 1). Seedlings were planted in May with 5 plants per plant pot.

The fertilizers used were: basic fertilizer N: P: K 12: 8: $16(+3 \mathrm{MgO}+\mathrm{Me})$ Nova Tec Classic, $600 \mathrm{~kg} / \mathrm{ha}$ rotated in soil before seedling (treatments 2-6) and low active ingredient containing organic fertilizer as a basic fertilizer at a dose of $35 \mathrm{t} / \mathrm{ha}$ (for treatment 2). Head fertilizer: $\mathrm{K}_{2} \mathrm{SO}_{4}(50 \%$ potassium sulphate) in different amounts $(0-200 \mathrm{~kg} / \mathrm{ha})$ and $\mathrm{NH}_{4} \mathrm{NO}_{3}(34 \%$ ammonium nitrate) 30 $\mathrm{kg} / \mathrm{ha}$ (for treatments 4-6) (Table 1).

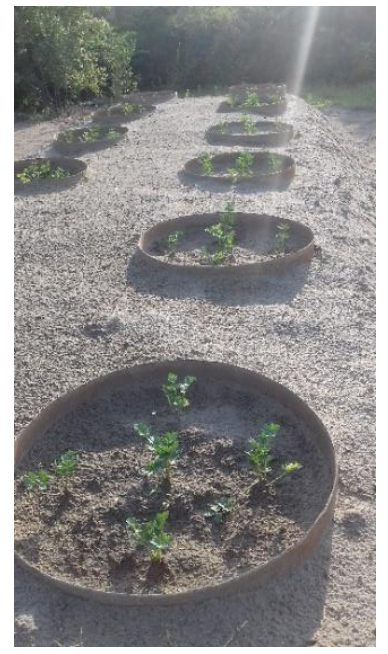

Figure 1. Test plants in lysimeter pots

Table 1. Fertilizer treatment methods (1-6)

\begin{tabular}{|c|l|c|c|c|c|c|c|}
\hline \multirow{2}{*}{\multicolumn{2}{|c|}{ Treatment }} & \multicolumn{4}{c|}{ Basic fertilzer (Nova Tec) } & \multicolumn{2}{c|}{ Head fertilizer } \\
\cline { 2 - 7 } & $\begin{array}{c}\mathrm{N} \\
(\mathrm{kg} / \mathrm{ha})\end{array}$ & $\begin{array}{c}\mathrm{P}_{2} \mathrm{O}_{5} \\
(\mathrm{~kg} / \mathrm{ha})\end{array}$ & $\begin{array}{c}\mathrm{K}_{2} \mathrm{O} \\
(\mathrm{kg} / \mathrm{ha})\end{array}$ & $\begin{array}{c}\text { Manure } \\
(\mathrm{kg} / \mathrm{ha})\end{array}$ & $\begin{array}{c}+\mathrm{K}_{2} \mathrm{O} \\
(\mathrm{kg} / \mathrm{ha})\end{array}$ & $+\mathrm{N}$ (kg/ha) \\
\hline 1 & Control & 0 & 0 & 0 & 0 & 0 & 0 \\
\hline 2 & Organic fertilizer & 72 & 48 & 66 & 35000 & 0 & 0 \\
\hline 3 & K0 & 72 & 48 & 66 & 0 & 0 & 0 \\
\hline 4 & K50 & 72 & 48 & 66 & 0 & 50 & 30 \\
\hline 5 & K100 & 72 & 48 & 66 & 0 & 100 & 30 \\
\hline 6 & K200 & 72 & 48 & 66 & 0 & 200 & 30 \\
\hline
\end{tabular}


During the growing season, the pots were kept mechanically free from weeds.

Harvesting was carried out at the end of the growing season in full ripening size (28 September 2017). Leaf, tuber and root weights were also measured per treatment and repetition.

After cleaning, the samples were taken to the laboratory of the faculty (accredited Soil and Plant Testing Laboratory), where the samples were processed. The crude samples were dried in a $70{ }^{\circ} \mathrm{C}$ thermostat, then grounded and homogenized. As we had problems, with grounding dried tuber, we had to omit it from element measurements. The main nutrients were analyzed by standard methods from celery leaf and root samples (microwave digestion of powdered plant parts and ICPOES spectrometric methods - for potassium, and magnesium).

Our results were statistically evaluated using SPSS 13.0 for Windows and Microsoft Office Excel. The mean values and standard deviations, as well as the differences between the effects of the treatments and the correlation coefficients at the $5 \%, 2 \%, 1 \%$ and $0.1 \%$ significance levels were determined.

\section{Results}

In our experiment, the untreated control gave the smallest total celery yield, while the highest yield was reached in organic fertilizer treatment, in the average of the four repetition (Table 2). It should be noted, however, that the yields in a treatment group showed considerable variation, especially in the case of absolute control, probably due to unequal irrigation.

There was no significant difference in yield weight between potassium control and potassium fertilizer treatments $\left(50,100,200 \mathrm{~K}_{2} \mathrm{O} \mathrm{kg} / \mathrm{ha}\right)$. The explanation for this is that the extra potassium fertilizer was applied to the surface of the soil a little bit late.

Table 2. Total yield of celery after different treatments

\begin{tabular}{|r|l|r|}
\hline \multicolumn{2}{|c|}{ Treatment } & Total weight (g/pot) \\
\hline 1 & Control & 329 \\
\hline 2 & Organic fertilizer & 1928 \\
\hline 3 & K0 & 957 \\
\hline 4 & K50 & 1079 \\
\hline 5 & K100 & 998 \\
\hline 6 & K200 & 993 \\
\hline
\end{tabular}

Regarding the nutrient content of the leaf and root, potassium level was the lowest in absolute control plants. Potassium fertilization gradually increased the potassium content in both the leaf and the root (from 1.28 to $3.21 \mathrm{~m} / \mathrm{m} \%$ in the leaf and from 1.69 to $3.18 \mathrm{~m} / \mathrm{m} \%$ in the root) (Table 3). The highest concentrations were resulted after manure treatment $(3.52$ and $4,52 \mathrm{~m} / \mathrm{m} \%$ in dry matter in leaf and root, respectively).

Potassium fertilizer treatment slightly reduced the magnesium content of both the leaf and the root. In the leaf, from 0.572 to $0.428 \mathrm{~m} / \mathrm{m} \%$, and in the root from 0.563 to $0.451 \mathrm{~m} / \mathrm{m} \%$. Magnesium concentration was the lowest in celery leaves.

Potassium levels in leaf and root were significantly increased after subsequently increasing potassium doses $(r=0.9853, p<0.01$ in leaf, and $r=0.8900 p<0.01$ in root).

Magnesium levels in leaf and root were significantly decreased after subsequently increasing potassium doses $(r=-0.9225, p<0.01$ in leaf, and $r=-0.7872 p<0.025$ in root).

Correlation was strong regarding both of the examined nutrients, but magnesium level showed strong negative correlation with higher potassium fertilizer doses. 
Table 3. Potassium and magnesium content of celery leaf and root after different treatments

\begin{tabular}{|l|l|r|r|r|r|}
\hline \multirow{2}{*}{ Treatment } & \multicolumn{2}{|c|}{ Leaf } & \multicolumn{2}{c|}{ Root } \\
\cline { 3 - 6 } & $\begin{array}{c}\mathrm{K} \mathrm{m} / \mathrm{m} \% \\
\text { dry matter }\end{array}$ & $\begin{array}{r}\text { Mg m/m\% } \\
\text { dry matter }\end{array}$ & $\begin{array}{c}\mathrm{K} \mathrm{m} / \mathrm{m} \% \\
\text { dry matter }\end{array}$ & $\begin{array}{c}\text { Mg m/m\% } \\
\text { dry matter }\end{array}$ \\
\hline 1 & Control & 0.401 & 0.561 & 0.791 & 0.376 \\
\hline 2 & $\begin{array}{l}\text { Organic } \\
\text { fertilizer }\end{array}$ & 3.52 & 0.571 & 4.52 & 0.521 \\
\hline 3 & K0 & 1.28 & 0.572 & 1.69 & 0.563 \\
\hline 4 & K50 & 1.57 & 0.594 & 2.10 & 0.640 \\
\hline 5 & K100 & 2.43 & 0.491 & 3.13 & 0.550 \\
\hline 6 & K200 & 3.21 & 0.428 & 3.18 & 0.451 \\
\hline
\end{tabular}

\section{Discussion}

Total celery yield was the lowest in control (treatment 1), and the highest yield was reached after organic manure treatment (treatment 2). There was no significant difference in total weight among potassium control and potassium fertilizer treatments $\left(50,100,200 \mathrm{~K}_{2} \mathrm{O} \mathrm{kg} / \mathrm{ha}\right.$ active potassium). Our former study showed, that at harvesting celery tuber weight and the ratio of it according to the whole plant, also increased with the increased $\mathrm{K}$ doses in general [8].

The results show that potassium fertilization in celery test plants increased potassium in a dose-dependent manner. The correlation was highly significant in leaf and root as well. However, magnesium level in the examined plant parts decreased significantly with higher potassium doses. These results are in accordance with other studies [9, 19], emphasizing that potassium and magnesium levels and their balances are important factors affecting the growth of plant. However, the responses of different crop cultivars to $\mathrm{K} / \mathrm{Mg}$ ratios are less clear $[1,2,10]$. Our results calls attention for magnesium supplementation in parallel with potassium fertilization in sandy soil with low cation absorbing capacity. Further studies are needed to follow the effects of higher potassium doses, the effects of potassium on other elements as well in different parts of the test plants.

\section{Conclusion}

Our results show that total plant weight and potassium content in plant parts was the highest after organic fertilization. We suggest that potassium fertilization in celery test plants increased potassium in a dose-dependent manner, whereas magnesium levels significantly decreased. Our results call attention for magnesium supplementation in parallel with potassium fertilization.

\section{Acknowledgment}

Authors wish to thank for the support of the research carried out in the framework of the EFOP3.6.2-16-2017-00012 „Developing a functional, healthy and safe food product chain model from field to table in a thematic research network". The project is funded by the Hungarian State and the European Union, co-financed by the European Social Fund, and is part of the Széchenyi 2020 program.

\section{References}

[1] Cakmak I. (2013) Magnesium in crop production, food quality and human health. Plant Soil, 368, pp. 1-4. 
[2] Chen Z-j, Zhou T., Liu Y., Zhou J-b. (2018) High potassium to magnesium ratio affected the growth and magnesium uptake of three tomato (Solanum lycopersicum L.) cultivars. Journal of Integrative Agriculture 17(12), pp.2813-2821.

[3] Cserni I., Végh K., Füleki Gy. (2000): Tápelemek modellezése és mérése a talajban zöldségnövények alatt. Kutatási zárójelentés a T023348 OTKA témáról 1997-1999. Kézirat. p. 50.

[4] Cserni I., Kovács N., Zana S.-né, Borsné Pető J. (2003): Az elemek (N,P,K) mobilitása homoktalajon. In: Nagyné Fehér I.(szerk.) II. Erdei Ferenc Tudományos Konferencia: 2003.augusztus 28-29., Kecskemét. pp. 277-281.

[5] Cserni I., N. Kovács, A. Zana, J. Borsné Pető (2004): The Migration of Elements (NPK) in Sandy Soil. III. AlpsAdria Scientific Workshop, Dubrovnik, 1-6 March 2004. pp. 30-34.

[6] Cserni I., Pető J., Hüvely A., (2015): A zeller növekedésének és egyes értékmérő paramétereinek vizsgálata, GRADUS 2:(2) pp. 236-241.

[7] Cserni I., Pető J., Hüvely A. (2017): Homoktalajok tápanyag-tartalma a tápanyag-ellátás függvényében, Talajvédelem 25 (különszám) pp. 357-362.

[8] Cserni I., Hüvely A., Pető J. (2019): Gumós Zeller (Apium graveolens) kálium trágyázási kísérlet. Gradus 6(2) pp. 216-221.

[9] Füleky Gy. (1999): Növényi tápanyagok a talajban. In: Stefanovits - Filep - Füleky (1999): Talajtan. Mezőgazda. pp. 191-220.

[10] Gransee, A., Führs, H. (2013). Magnesium mobility in soils as a challenge for soil and plant analysis, magnesium fertilization and root uptake under adverse growth conditions. Plant Soil, 368, pp. 5-21.

[11] Kádár I. (1999/a): Tápanyaggazdálkodás Magyarország homoktalajain. International Potash Institute Basel/Switzerland, MTA TAKI., Budapest, Jász Nyomda- és Kiadó Kft. p. 34.

[12] Kádár I. (1999/b): Kálium és jelentősége Magyarországon. International Potash Institute Basel/Switzerand,. MTA TAKI., Budapest, Jász Nyomda- és Kiadó Kft. p. 32.

[13] Loch J., Noszticzius Á. (1992): Agrokémia és növényvédelmi kémia. Mezőgazda Kiadó. p. 399.

[14] Nyle C. Bredy, Ray R.Weil (1999): The Nature and Properties of Soils. Canada Inc. Toronto. p. 881.

[15] Stefanovits P. (1966): Hazánk homoktalajainak jellemzése. In: Antal-Egerszegi-Penyigei: Növénytermesztés homokon. Mezőgazda Kiadó. Budapest. pp. 9-22.

[16] Stefanovits P.(1985): Clay mineral content of soils and fertilizer use. Agrokémia és Talajtan. 34. Suppl. pp. 6572.

[17] Tölgyesi Gy (1992): Trágyázás kertészetekben. Budapest.Agricola.p.103.

[18] Várallyay Gy. et.al. (1980): Magyarország termőhelyi adottságait meghatározó talajtani tényezők 1:100 000 méretarányú térképe. Agrokémia és Talajtan 29. pp. 149-156.

[19] Zlámalová, T., Elbl, J., Baroň, M., Bělíková, H., Lampíř, L., Hlušek, J., Lošák, T. (2015) Using foliar applications of magnesium and potassium to improve yields and some qualitative parameters of vine grapes (Vitis vinifera, L.). Plant, Soil and Environment, 61, pp. 451-457. 